\title{
E-LEARNING DALAM PEMBELAJARAN MATEMATIKA
}

Oleh

Muh.Rais

Muhrais035@gmail.com

\begin{abstract}
Abstrak
E-learning merupakan suatu konsep pendidikan yang memanfaatkan perkembangan teknologi informasi dan komunikasi khususnya dalam proses pengajaran. Kemudahan penggunaan e-learning juga terletak pada kenyataan bahwa guru dapat menggunakan media dan sumber belajar yang lebih menarik untuk mempersiapkan pembelajaran secara efektif, sehingga tidak harus fokus pada buku cetak. Hal ini dapat meningkatkan minat belajar siswa ketika pembelajaran tidak lagi difokuskan pada guru dan kelas. Fungsi e-learning dalam menunjang kegiatan pembelajaran di kelas adalah sebagai pelengkap, pelengkap dan pengganti Peran elearning dalam dunia pendidikan sudah mulai berubah peran dan statusnya dari asalnya sebagai suatu sistem atau perangkat. Menjadi media penyampaian informasi pembelajaran. E-learning diciptakan untuk mengatasi keterbatasan antara pendidik dan peserta didik terutama dalam hal waktu, ruang, kondisi, dan lingkungan. Melalui elearning, pendidik dan peserta didik tidak harus berada dalam satu dimensi ruang dan waktu. E-learning memberikan banyak bantuan, sehingga dapat meningkatkan hasil belajar matematika siswa. Akan tetapi, materi matematika bersifat abstrak, sehingga sebagian besar siswa menganggap matematika itu sulit. Inilah salah satu penyebab gagal mencapai tujuan pembelajaran matematika. Konsep matematika yang spesifik dan mengikuti waktu yang dialami siswa dapat dengan mudah dipahami. Sekolah menengah pertama menuntut siswa untuk dapat bernalar dan menggunakan hal-hal yang abstrak dan simbolis. Solusi tersebut dapat membantu siswa memahami penggunaan e-learning untuk pembelajaran.
\end{abstract}

\section{A.Latar Belakang}

Pendidikan merupakan kebutuhan yang sangat penting bagi kehidupan setiap manusia. Sebab pendidikan adalah usaha sadar dan terencana yang dilakukan untuk 
mengembangkan potensi yang ada dalam dirinya sendiri untuk mengembangkan kemampuan berpikir, akhlak, pengetahuan, kepribadian dan spiritual agama untuk kebutuhan mereka di masyarakat.(Rodiawati \& Komarudin, 2018). Mereka yang mendapat jasa pendidikan kemudian menjadi manusia dewasa yang memiliki kualifikasi ahli, terampil, kreatif, inovatif, serta memiliki sikap dan perilaku yang positif. Kualitas manusia Indonesia masa depan harus lebih baik karena kemajuan suatu bangsa diwarnai dengan sumber daya manusia yang berkualitas.(Danial dkk., 2019)

Teknologi baru terutama dalam bidang ICT memiliki peran yang semakin penting dalam pembelajaran. Banyak orang percaya bahwa multimedia akan dapat membawa kita kepada situasi belajar dimana "learning with effort" akan dapat digantikan dengan " learning with fun". Apalagi dalam pembelajaran orang dewasa, learning with effort menjadi hal yang cukup menyulitkan untuk dilaksanakan karena berbagai faktor pembatas seperti usia, kemampuan daya tangkap, kemauan berusaha, dll. Jadi proses pembelajaran yang menyenangkan, kreatif, tidak membosankan menjadi pilihan para fasilitator. Jika situasi belajar seperti ini tidak tercipta, paling tidak multimedia dapat membuat belajar lebih efektif menurut pendapat beberapa pengajar. Pada saat ini kita semua memahami bahwa "proses belajar" dipandang sebagai proses yang aktif dan partisipatif, konstruktif, kumulatif, dan berorientasi pada tujuan pembelajaran, baik Tujuan Pembelajaran Umum (TPU) maupun Tujuan Pembelajaran Khusus (TPK).(Elyas, 2018)

Pengembangan e-learning ini juga memang menjadi kecenderungan dan pilihan karena adanya perubahan dalam kehidupan. Pada era globali- sasi saat ini terjadi perubahan paradigma dalam dunia pendidikan. Pendi- dikan yang berlangsung sekarang setidaknya menghadapi dua tantangan. Tantangan yang pertama berasal dari adanya perubahan pandangan terhadap belajar itu sendiri. Pandangan behaviorisme yang mengutamakan stimulus dan respons tidak cukup untuk dapat memberikan hasil optimal. Pembaharuan paradigma belajar melalui pandangan konstruktivisme dan pergeseranpergeseran yang terjadi karena adanya kemajuan teknologi in-formasi dan komunikasi merupakan dua hal yang sangat sejalan dan saling memperkuat.(Universitas Jambi \& Kusmana, 2011) 
Matematika merupakan salah satu mata pelajaran wajib pada jenjang sekolah dasar, sekolah menengah pertama dan sekolah menengah atas. Pembelajaran matematika membutuhkan interaksi antara guru dan siswa serta antarsiswa untuk menyelesaikan sebuah masalah matematika.(Islamiah, 2020) . Pembelajaran matematika di sekolah diharapkan menjadi sesuatu yang menyenangkan bagi peserta didik, tetapi kenyataannya masih banyak kesulitan yang ditemui dalam mempelajari matematika. Peristiwa yang sering terjadi dalam pembelajaran matematika adalah peserta didik kurang aktif, kurang berpartisipasi dan peserta didik terkesan hanya sebagai pendengar yang di informasikan oleh guru.(Fitriani \& Nurjannah, 2019)

Penggunaan media pembelajaran online sebagai sistem pembelajaran yang baru, mendorong penyelenggaraan pembelajaran semakin efektif. Dengan media pembelajaran online dimungkinkan banyak pembelajaran yang diperoleh sehingga memberikan pelayanan kepada siswa lebih memuaskan. Idealnya pengajar dan pembelajar senantiasa mengakses berbagai informasi dengan cepat, bertanggung jawab dan sesuai harapan.(Irmayanti \& Rais, 2021)

Menurut (Muthy \& Pujiastuti, 2020) Revolusi digital akan secara otomatis merubah segala aspek pendidikan dari awalnya adalah pertemuan hanya dilakukan secara tatap muka dimana guru akan menjelaskan langsung di depan siswa dengan penampilan mengajar yang telah dipelajari menjadi sebuah pertemuan dimana siswa dan guru berada di tempat yang berbeda namun proses pembelajaran tetap berlangsung, dan penampilan guru dalam memaparkan atau memberikan materi menjadi sangat penting, seperti contohnya guru dapat memberikan materi melalui video kreatif atau aplikasi dalam smartphone yang memudahkan siswa untuk memamahami materi lebih mendalam.

\section{B.Rumusan Masalah}

1. Apakah yang dimaksud Pengertian E-Learning?

2. Apakah yang dimaksud Tipe E-learning?

3. Apakah yang dimaksud komponen E-Learning?

4. Bagaimanakah Kelebihan Dan Kekurangan E-Learning?

5. Bagaimanakah Peranan E-Learning Dalam Pembelajaran Matematika? 
6. Bagaimanakah Teknologi Pendukung E-learning?

C. Tujuan Penulisan Makalah

Tujuan dari penulisan makalah ini untuk mengetahui dan memahami pengertian, tipe, komponen, kelebihan dan kekurangan serta peranan E-learning dalam pembelajaran matematika. Selain itu, penulisan makalah ini juga bertujuan untuk memenuhi salah satu tugas mata kuliah Metodologi Penelitian Pendidikan Matematika 


\section{A.Pengertian E-Learning}

E-Learning merupakan suatu teknologi informasi yang relatif baru diindonesia.ELearning terdiri dua bagian yaitu 'e' yang merupakan singkatan dari 'electronic' dan 'learning' yang berarti 'pembelajaran'.jadi e-learning berarti pembelajaran dengan menggunakan jasa bantuan perangkat elektronika, khususnya perangkat komputer.(Universitas Jambi \& Kusmana, 2011)

E-learning adalah suatu kemajuan penting dalam sistem pendidikan modern. Elearning ini membawa pengaruh terjadinya proses transformasi pendidikan konvensional ke dalam bentuk digital, baik secara isi (contents) maupun sistemnya.(Ompusunggu \& Sari, 2019)

Dalam perkembanganya, komputer dipakai sebagai alat bantu pem- belajaran, karena itu dikenal dengan istilah (CBL) atau computer assisted learning (CAL). Saat pertama kali komputer mulai diperkenalkan khu- susnya untuk pembelajaran, maka komputer menjadi popular di kalangan anak didik. Hal ini dapat dimengerti karena berbagai variasi teknik meng- ajar bisa dibuat dengan bantuan komputer tersebut. Maka setelah itu teknologi pembelajaran terus berkembang dan dikelompokkan menjadi dua yaitu :

\section{Technology-based learning}

\section{Technology-based Web-learning}

Technology based-learning ini pada prinsipnya terdiri dari dua, yaitu audio (audio tape, radio, voice mail, telepon) an video information technologies (video tape, video text, video messaging). Sedangkan technology based web-learning pada dasarnya adalah data information technologies (bulletin board, internet, email, tele-collaboration).

Dalam pelaksanaan pembelajaran sehari-hari, yang sering dijumpai adalah kombinasi dari teknologi yang dituliskan di atas (audio/data, video/data, audio/video). Teknologi ini juga sering dipakai pada pendidik- an jarak jauh, dimaksudkan agar komunikasi antara murid dan guru bisa terjadi dengan keunggulan teknologi e-learning ini. Sedangkan interaksi antara guru dan murid bisa dilaksanakan melalui cara langsung 
(syn- chronous) atau tidak langsung, misalnya pesan direkam dahulu sebelum digunakan. Cara ini dikenal dengan nama e-synchronous.

Karakteristik e-learning antara lain adalah:

a. Memanfaatkan jasa teknologi elektronik; dimana guru dan siswa, siswa dan sesama siswa atau guru dan sesama guru dapat berkomunikasi de- ngan relatif mudah dengan tanpa dibatasi oleh hal-hal yang protokelor;

b. Menggunakan bahan ajar bersifat mandiri (self learning materials) disim- pan di komputer sehinga dapat diakses oleh guru dan siswa kapan saja dan dimana saja dan yang bersangkutan memerlukanya; dan

c. Memanfaatkan jadwal pembelajaran, kurikulum, hasil kemajuan belajar dan hal-hal yang berkaitan dengan administrasi pendidikan dapat dili- hat setiap saat di komputer.

Menurut (Hartanto, 2016)Berbagai istilah digunakan untuk mengemukakan pendapat/gagasan tentang pembelajaran elektronik, antara lain adalah: onlinelearning, internet-enabled learning, virtual learning, atau web-based learning

.Ada 3 (tiga) hal penting sebagai persyaratan kegiatan belajar elektronik(e-learning), yaitu:

1) kegiatan pembelajaran dilakukan melalui pemanfaatan jaringan, dalam hal ini dibatasi pada penggunaan internet,

2) tersedianya dukungan layanan belajar yang dapat dimanfaatkan oleh peserta belajar, misalnya External Harddisk, Flaskdisk, CD-ROM, atau bahan cetak, dan

3) tersedianya dukungan layanan tutor yang dapat membantu peserta belajar apabila mengalami kesulitan.

Di samping ketiga persyaratan tersebut di atas masih dapat ditambahkan persyaratan lainnya, seperti adanya:

1) lembaga yang menyelenggarakan dan mengelola kegiatan e-learning,

2) sikap positif dari peserta didik dan tenaga kependidikan terhadap teknologi komputer dan internet, 
3) rancangan sistem pembelajaran yang dapat dipelajari dan diketahui oleh setiap peserta belajar,

4) sistem evaluasi terhadap kemajuan atau perkembangan belajar peserta belajar, dan

5) mekanisme umpan balik yang dikembangkan oleh lembaga penyelenggara.

Dikarenakan berbagai penggunaan e-learning saat ini, istilah "e-learning" memiliki banyak arti. Pada dasarnya ada dua jenis pembelajaran, yaitu sinkron dan asinkron. Ini juga berarti sinkronisasi. Proses pembelajaran berlangsung secara bersamaan antara pendidik dan siswa. Ini memungkinkan interaksi online langsung antara pendidik dan siswa. Dalam implementasinya, pelatihan serentak mengharuskan pendidik dan siswa untuk mengakses Internet secara bersamaan. Pendidik memberikan materi pembelajaran berupa karangan atau slide presentasi, dan siswa dapat mendengarkan presentasi secara langsung melalui internet. Siswa juga dapat mengajukan pertanyaan atau komentar secara langsung atau melalui jendela obrolan. Pelatihan sinkron adalah kursus nyata, tetapi juga virtual (virtual), dan semua siswa terhubung melalui Internet.

\section{B.Tipe E-Learning}

Dalam e-Learning komunikasi dapat dilakukan dengan dua cara yaitu tipe synchronous dan asynchronous. Istilah tersebut berasal dari kata dasar synchronous yang berasal dari Bahasa Jerman kemudian diserap ke dalam Bahasa Inggris. Kata synchron (singkron) memiliki arti serempak atau serentak. Pada kata synchronous kata dasar synchron diberi akhiran (suffixes) - ous sehingga membentuk makna turunan dari kata dasar, sedangkan kata asynchronous mendapat tambahan awalan a- yang berarti mempunyai makna berlawanan dengan kata awal. Kedua jenis tipe tersebut dapat digunakan secara bersamaan ataupun bergantian dalam e-Learning(Mutiasari dkk., 2019).

Sinkronisasi artinya "secara bersamaan". Oleh karena itu, sinkronisasi adalah jenis proses pembelajaran di mana guru mengajar dan siswa belajar pada waktu yang bersamaan. Ini memungkinkan interaksi langsung antara guru dan siswa melalui Internet dan Intranet. E-learning sinkron terutama digunakan dalam seminar atau 
pertemuan dengan peserta dari berbagai negara / wilayah. Penggunaan ini sering disebut konferensi web atau seminar web (web seminar), dan sering digunakan oleh kursus atau kuliah universitas online.

Sinkronisasi mengharuskan guru dan semua siswa untuk mengakses Internet pada waktu yang sama. Guru memberikan slide presentasi untuk makalah melalui Internet. Peserta juga dapat mengajukan pertanyaan atau komentar melalui jendela obrolan. Oleh karena itu, sinkronisasi mirip dengan pelatihan di kelas. Namun, kursus ini bersifat virtual (virtual), dengan peserta di seluruh dunia dan terhubung melalui Internet. Oleh karena itu, sinkronisasi sering disebut sebagai ruang kelas virtual.

Asynchronous artinya "tidak pada waktu yang sama". Oleh karena itu, seseorang dapat memperoleh materi pembelajaran pada waktu yang berbeda sedangkan guru memberikan pembelajaran. Jenis pembelajaran e-learning ini lebih populer di dunia elearning karena memberikan manfaat lebih kepada siswa karena mereka dapat mengakses pembelajaran kapanpun dan dimanapun. Pembelajaran berbentuk paket kursus, yang dapat dijalankan di komputer atau android apa pun, dan tidak perlu berinteraksi dengan guru atau siswa lain. Oleh karena itu, siswa dapat menghadiri dan menyelesaikan kursus kapan saja. Paket kursus mengadopsi bentuk membaca, termasuk animasi, simulasi, game edukasi atau latihan atau kursus dengan jawaban. Guru juga dapat memberikan tugas atau latihan, dan peserta dapat mengirimkan tugas melalui email. Peserta dapat menggunakan papan buletin untuk berdiskusi atau memberi komentar dan mengajukan pertanyaan.

\section{C.Komponen E-Learning}

Menurut (Mutiasari dkk., 2019)secara garis besar, apabila kita menyebut tentang $e$ Learning, ada tiga komponen utama yang menyusun e-Learning tersebut. Diantaranya yaitu sebagai berikut.

\section{1. e-Learning System}

Sistem perangkat lunak yang memvirtualisasi proses belajar mengajar konvensional. Bagaimana manajemen kelas, pembuatan materi atau konten, forum diskusi, sistem penilaian (raport), sistem ujian online dan segala fitur yang berhubungan dengan 
manajemen proses belajar mengajar. Sistem perangkat lunak tersebut sering disebut dengan LMS (Learning Management System).

\section{2. e-Learning Content (Isi)}

Konten dan bahan ajar yang ada pada e-Learning system (Learning Management System). Konten dan bahan ajar ini bisa dalam bentuk Multimediabased Content (konten berbentuk multimedia interaktif) atau Text-based Content (konten berbentuk teks seperti pada buku pelajaran biasa.).

3. e-Learning Infrastructue (Peralatan)

Infrastruktur e-Learning dapat berupa personal computer (PC), jaringan computer dan perlengkapan multimedia. Termasuk di dalamnya peralatan teleconference apabila kita memberikan layanan synchronous learning melalui teleconference.

\section{D.Kelebihan dan Kekurangan E-learning}

Menyadari bahwa melalui internet dapat ditemukan berbagai infor- masi yang dapat diakses secara mudah, kapan saja dan dimana saja, ma pemanfaatan internet menjadi suatu kebutuhan. Bukan itu saja, pengguna internet bisa berkomunikasi dengan pihak lain dengan cara yang sangat mudah melalui teknik e-moderating yang tersedia di internet.(Universitas Jambi \& Kusmana, 2011)

Berdasarkan berbagai pengalaman dan berbagai informasi yang diberikan dalam literatur, petunjuk tentang manfaat menggunakan internet berikut ini dapat diberikan, khususnya dalam pendidikan terbuka dan jarak jauh.

1. Dengan tersedianya fasilitas mediasi elektronik, guru dan siswa dapat dengan mudah berkomunikasi melalui internet secara rutin maupun selama melakukan kegiatan komunikasi, terlepas dari jarak, lokasi, dan waktu.Guru dan siswa dapat menggunakan buku teks terstruktur dan terjadwal atau instruksi pembelajaran melalui Internet sehingga kedua belah pihak dapat mengevaluasi tingkat pembelajaran buku teks tersebut.

2. Jika perlu, siswa dapat mempelajari atau mereview buku teks kapanpun dan dimanapun, sambil mengingat bahwa buku teks tersebut telah disimpan di komputer. 
3. Jika siswa membutuhkan informasi lain terkait materi yang mereka pelajari, mereka dapat mengakses Internet.Baik guru maupun siswa dapat berdiskusi melalui Internet, dan kemudian sejumlah besar peserta berpartisipasi, sehingga meningkatkan pengetahuan dan wawasan yang lebih luas.

4. Ubah peran siswa dari biasa pasif menjadi aktif.Relatif lebih efisien. Misalnya, bagi mereka yang jauh dari kehidupan kuliah atau sekolah biasa, mereka yang sibuk dengan pekerjaan, mereka yang bekerja di kapal, di luar negeri, dll.

Namun penggunaan internet untuk pembelajaran atau e-learning juga tidak terlepas dari berbagai kekurangannya. Berbagai kritik dapat dikatakan sebagai berikut:

1. Terdapat kurangnya interaksi antara guru dan siswa dan bahkan antara siswa itu sendiri. Kurangnya interaksi akan memperlambat pembentukan nilai-nilai dalam proses pengajaran.

2. Kecenderungan untuk mengabaikan tren akademik atau sosial, dan sebaliknya, mendorong pertumbuhan bisnis.

3. Proses belajar mengajar cenderung berupa pelatihan daripada pendidikan.

4. Sekarang juga dituntut untuk mengubah peran guru dan orang-orang yang telah menguasai teknologi pembelajaran tradisional agar dapat memahami teknologi pembelajaran yang menggunakan TIK.

5. Siswa yang tidak termotivasi untuk belajar seringkali gagal. Fasilitas internet tidak tersedia di mana-mana (mungkin ini terkait dengan kurangnya pengetahuan komputer (masalah ketersediaan, listrik, telepon atau komputer).

E. Peranan E-learning dalam Pembelajaran Matematika

E-learning adalah cara baru dalam proses belajar mengajar. E-learning merupakan dasar dan konsekuensi logis perkembangan teknologi informasi dan komunikasi. Dengan e-learning peserta didik tidak perlu duduk manis di ruang kelas. E-Learning dapat mempersingkat target waktu pembelajaran dan menghemat biaya membeli buku paket. Pembelajaran e-learning juga akan berpusat pada peserta didik dimana peserta 
didik mampu belajar dan mengakses informasi belajarnya dimana saja dan kapan saja sehingga belajar akan lebih mudah, praktis dan efisien.(Fitriani \& Nurjannah, 2019)

Pada dasarnya e-learning memiliki kegunaan yang luas dalam pendidikan matematika, dapat digunakan sebagai media pembelajaran di dalam kelas maupun sebagai media pembelajaran mandiri. Pembelajaran di kelas dapat membantu membawa konteks ke dalam kelas untuk ditunjukkan kepada siswa melalui penggunaan media visual atau audiovisual. Menerapkan konsep matematika tanpa harus melihat secara langsung, metode pembelajaran ini dapat diterapkan pada siswa SMP yang sesuai dengan teori perkembangan psikologi Piaget pada tahap operasi formal, sehingga mereka dapat mulai berpikir secara abstrak di awal. Penggunaan media pada siswa sekolah menengah pertama, misalnya menggunakan XL untuk memahami pengolahan data dalam data statistik, simulasi ruang arsitektural, dll.

Selain mempelajari matematika pada level yang lebih tinggi, saat menggunakan software seperti Mathematica, Maple, Matlab, Fortran, Basica, Geometer Skechtpad, Cabri, Minitab, SPSS, Microsoft, dll. Untuk input seperti Kalkulus, Geometri, Nilai Numerik, Diskrit dan Probabilitas dan Statistik Hasil penelitian menunjukkan bahwa konsep kelas dapat meningkatkan kemampuan berpikir tingkat tinggi dan minat belajar matematika. Jika melihat ciri-ciri matematika, sebenarnya materi tertentu (seperti metode numerik atau program linier dengan menggunakan media komputer) sangat diperlukan, karena dalam kasus yang lebih kompleks, perhitungan dilakukan secara manual.

Gunakan media elektronik untuk belajar. Dan pembelajaran online Namanya "elearning" dan dipublikasikan dengan menggunakan media elektronikHubungkan ke Internet (World Wide Web yang menghubungkan semua unit komputerInternet di seluruh dunia) dan Intranet (bisaHubungkan semua unit komputer di perusahaan). kalau sudah Hubungkan komputer Anda ke Internet untuk berpartisipasi dalam elearning. Dengan cara ini, peserta didik yang dapat berpartisipasi bisa lebih banyak Lebih besar dari cara belajar tradisional di kelas (jumlah siswaTerbatas untuk ukuran ruang kelas). Teknologi ini juga dapat mencapai pengiriman Dibandingkan dengan pembelajaran di kelas, kursus dengan standar kualitas yang lebih tinggi Itu tergantung pada "emosi" dan kondisi fisik pelatih. Dalam e-learning, modul yang sama 
(informasi, tampilan dan kualitas pembelajaran) dapat diakses di lokasi berikut Semua siswa yang menggunakan formulir yang sama saat belajar Di kelas, karena masalah kesehatan atau pribadi, tidak ada pengajarBeberapa pelajaran dengan kualitas berbeda dapat diberikan.

\section{F. Teknologi Pendukung E-learning}

Dalam prakteknya e-learning memerlukan bantuan teknologi. Karena itu dikenal istilah: computer based learning (CBL) yaitu pembelajaran yang sepenuhnya menggunakan komputer; dan computer assisted learning (CAL) yaitu pembelajaran yang menggunakan alat bantu utama komputer. Teknologi pembelajaran terus berkembang. Namun pada prinsipnya teknologi tersebut dapat dikelompokkan menjadi dua, yaitu: Technology based learning dan Technology based web-learning. Technology based learning ini pada prinsipnya terdiri dari Audio Information Technologies (radio, audio tape, voice mail telephone) dan Video InformationTechnologies (video tape, video text, video messaging). Sedangkan technology based weblearning pada dasarnya adalah

Data Information Technologies (bulletin board, Internet, e-mail, telecollaboration).(Elyas, 2018)

Dalam pelaksanaan pembelajaran sehari-hari, yang sering dijumpai adalah Kombinasi teknologi yang tercantum di atas (audio / data, video / data, audio / video). Teknologi ini juga sering digunakan dalam pendidikan jarak jauh. Dirancang untuk memungkinkan komunikasi yang baik antara siswa dan guru Teknologi e-learning ini. Untuk paradigma pendidikan online ini, ada beberapa pilihan yang salahSalah satunya adalah "sistem pendidikan dot.com". Paradigma iniBeberapa sistem dapat diintegrasikan, misalnya, pertama-tama, paradigma guru virtual Sumber daya yang dapat mengatasi sejumlah guru yang berkualitas dan memungkinkan siswaKarena peran guru virtual, saya tidak ingin mendapat dukungan kuat dari guru(Guru virtual), sebagian besar diambil alih oleh sistem pembelajaran. Dua, virtualSistem sekolah dapat memberikan kesempatan pada pendidikan dasar,Mid-high tidak membutuhkan ruang dan waktu. Keunggulan teladanKemampuan siswa ini tidak terbatas. Siswa dapat melakukan kegiatan pembelajaranKapanpun, dimanapun, kapanpun, dimanapun. 
Ketiga, paradigma sumber daya pendidikan onlineSumber daya sistem atau sistem kompresititik. 


\section{A. Kesimpulan}

E-learning merupakan suatu konsep pendidikan yang memanfaatkan perkembangan teknologi informasi dan komunikasi khususnya dalam proses pengajaran. Kemudahan penggunaan e-learning juga terletak pada kenyataan bahwa guru dapat menggunakan media dan sumber belajar yang lebih menarik untuk mempersiapkan pembelajaran secara efektif, sehingga tidak harus fokus pada buku cetak. Hal ini dapat meningkatkan minat belajar siswa ketika pembelajaran tidak lagi difokuskan pada guru dan kelas. Fungsi elearning dalam menunjang kegiatan pembelajaran di kelas adalah sebagai pelengkap, pelengkap dan pengganti Peran e-learning dalam dunia pendidikan sudah mulai berubah peran dan statusnya dari asalnya sebagai suatu sistem atau perangkat. Menjadi media penyampaian informasi pembelajaran. E-learning diciptakan untuk mengatasi keterbatasan antara pendidik dan peserta didik terutama dalam hal waktu, ruang, kondisi, dan lingkungan. Melalui e-learning, pendidik dan peserta didik tidak harus berada dalam satu dimensi ruang dan waktu. E-learning memberikan banyak bantuan, sehingga dapat meningkatkan hasil belajar matematika siswa. Akan tetapi, materi matematika bersifat abstrak, sehingga sebagian besar siswa menganggap matematika itu sulit. Inilah salah satu penyebab gagal mencapai tujuan pembelajaran matematika. Konsep matematika yang spesifik dan mengikuti waktu yang dialami siswa dapat dengan mudah dipahami. Sekolah menengah pertama menuntut siswa untuk dapat bernalar dan menggunakan hal-hal yang abstrak dan simbolis. Solusi tersebut dapat membantu siswa memahami penggunaan elearning untuk pembelajaran.

E-Learning merupakan suatu teknologi informasi yang relatif baru diindonesia.ELearning terdiri dua bagian yaitu 'e' yang merupakan singkatan dari 'electronic' dan 'learning' yang berarti 'pembelajaran'.jadi e-learning berarti pembelajaran dengan menggunakan jasa bantuan perangkat elektronika, khususnya perangkat komputer.Dalam $e$ Learning komunikasi dapat dilakukan dengan dua cara yaitu tipe synchronous dan asynchronous. Istilah tersebut berasal dari kata dasar synchronous yang berasal dari Bahasa Jerman kemudian diserap ke dalam Bahasa Inggris. Kata synchron (singkron) memiliki arti serempak atau serentak. Pada kata synchronous kata dasar synchron diberi akhiran (suffixes) -ous sehingga membentuk makna turunan dari kata dasar, sedangkan kata asynchronous mendapat tambahan awalan a- yang berarti mempunyai makna berlawanan dengan kata awal. Kedua jenis tipe tersebut dapat digunakan secara bersamaan ataupun bergantian dalam e-Learning

Pada dasarnya e-learning memiliki kegunaan yang luas dalam pendidikan matematika, dapat digunakan sebagai media pembelajaran di dalam kelas maupun sebagai media pembelajaran mandiri. Pembelajaran di kelas dapat membantu membawa konteks ke dalam kelas untuk ditunjukkan kepada siswa melalui penggunaan media visual atau audiovisual. Menerapkan konsep matematika tanpa harus melihat secara langsung, metode pembelajaran ini dapat diterapkan pada siswa SMP yang sesuai dengan teori 
perkembangan psikologi Piaget pada tahap operasi formal, sehingga mereka dapat mulai berpikir secara abstrak di awal.

\section{B. Saran}

Dari makalah yang singkat ini mudah-mudahan dapat bermanfaat bagi kita semua umumya kami pribadi. Dan kami sadar bahwa makalah kami masih jauh dari kata sempurna, masih banyak kesalahan dari berbagai sisi terutama dari referensi yang kami dapat. Jadi kami berharap saran dan kritik nya yang bersifat membangun, untuk memperbaiki makalah-makalah selanjutnya. 


\section{DAFTAR PUSTAKA}

Danial, D., Nurjannah, N., \& Mirna, M. (2019). . Evaluation of The Learning Program of Mathematics Study Program at Islamic Institute Of Muhammadiyah Sinjai. MATEMATIKA DAN PEMBELAJARAN, 7(1), 65. https://doi.org/10.33477/mp.v7i1.1046

Elyas, A. H. (2018). PENGGUNAAN MODEL PEMBELAJARAN E-LEARNING DALAM MENINGKATKAN KUALITAS PEMBELAJARAN. 11.

Fitriani, \& Nurjannah. (2019). PERANAN E-LEARNING DALAM PEMBELAJARAN MATEMATIKA DI SEKOLAH MENENGAH PERTAMA (SMP).

Hartanto, W. (2016). Penggunaan E-Learning Sebagai Media Pembelajaran. http://jurnal.unej.ac.id/index.php/JPE/article/view/3438

Irmayanti, \& Rais, M. (2021). INOVASI PEMBELAJARAN DENGAN MENGGUNAKAN EDMODO [Preprint]. Open Science Framework. https://doi.org/10.31219/osf.io/v4n2g

Islamiah, N. (2020). ANALISIS SOSIOMATEMATIKA BERBASIS KEARIFAN LOKAL DALAM PEMBELAJARAN PADA SISWA SDN 224 PALAE. 1(2), 8.

Muthy, A. N., \& Pujiastuti, H. (2020). Analisis media pembelajaran e-learning melalui pemanfaatan teknologi dalam pembelajaran matematika di rumah sebagai dampak 2019-nCoV. Jurnal Math Educator Nusantara: Wahana Publikasi Karya Tulis Ilmiah di Bidang Pendidikan Matematika, 6(1), 94-103. https://doi.org/10.29407/jmen.v6i1.14356

Mutiasari, D., Siska, R. R., \& Salelenggu, N. R. (2019). PERANAN E-LEARNING DALAM PEMBELAJARAN MATEMATIKA. 8.

Ompusunggu, V. D. K., \& Sari, N. (2019). EFEKTIFITAS PENGGUNAAN ELEARNING BERBASIS EDMODO TERHADAP KEMAMPUAN KOMUNIKASI MATEMATIKA. JURNAL CURERE, 3(2). https://doi.org/10.36764/jc.v3i2.250

Rodiawati, H., \& Komarudin, K. (2018). PENGEMBANGAN E-LEARNING MELALUI MODUL INTERAKTIF BERBASIS LEARNING CONTENT DEVELOPMENT SYSTEM. Jurnal Tatsqif, 16(2), 172-185. https://doi.org/10.20414/jtq.v16i2.190 Universitas Jambi, \& Kusmana, A. (2011). E-LEARNING DALAM PEMBELAJARAN. Lentera Pendidikan : Jurnal Ilmu Tarbiyah dan Keguruan, 14(1), 35-51. https://doi.org/10.24252/lp.2011v14n1a3 